Jurnal Visionida, Volume 4 Nomor 1 Juni 2018

\title{
PENGARUH BAURAN PEMASARAN JASA TERHADAP STRATEGI KEPUASAN PELANGGAN PADA NIKI SAE BUILDING BOGOR
}

\section{EFFECT OF SERVICE MARKETING MIX TO CUSTOMER SATISFACTION ON NIKI SAE BUILDING BOGOR}

\author{
Ade Rosadi $^{1)}$; Dwi Gemina ${ }^{2)}$ \\ Program Studi Manajemen Fakultas Ekonomi Universitas Djuanda Bogor \\ Email: aderosadi001@gmail.com; dwigemina@gmail.com \\ Correspondence author: dwigemina@gmail.com
}

\begin{abstract}
The purpose of this research is to know the customer's response and the influence of service marketing mix to customer satisfaction and supporting and inhibiting factors at Niki Sae Building Bogor, and the object of this research is customer 100 samples. Verifikatif form of research, tested the validity, reliability test and classical assumptions. Multiple linear regression analysis. The results of the average research of customer responses to the service marketing mix: product (good); price (affordables); location (convenient); promotion (interesting); people (good); process (easy); physical evidence (comfortable). Average customer response to customer satisfaction (satisfactory). Simultaneously the marketing mix has a positive and significant effect on customer satisfaction. Partially shows that product, price, person, process, and physical evidence have positive and significant influence to customer satisfaction as well as supporting factor, while location, promotion has no positive and significant effect to customer satisfaction as inhibiting factor.
\end{abstract}

Keywords: Marketing Service Mix, Customer Satisfaction, Niki Sae Building and Bogor

\begin{abstract}
ABSTRAK
Tujuan penelitian untuk mengetahui tanggapan pelanggan dan pengaruh bauran pemasaran jasa terhadap kepuasan pelanggan serta faktor pendukung dan penghambat pada Niki Sae Building Bogor, dan objek pada penelitian ini adalah pelanggan sebanyak 100 sampel. Bentuk penelitian verifikatif, dilakukan uji validitas, uji reliabilitas dan asumsi klasik. Analisis regresi linier berganda. Hasil penelitian rata-rata tanggapan pelanggan terhadap bauran pemasaran jasa: produk (baik); harga (terjangkau); lokasi (nyaman); promosi (menarik); orang (baik); proses (mudah); bukti fisik (nyaman). Tanggapan rata-rata pelanggan terhadap kepuasan pelanggan (memuaskan). Secara simultan bauran pemasaran berpengaruh positif dan signifikan terhadap kepuasan pelanggan. Secara parsial menunjukkan bahwa produk, harga, orang, proses, dan bukti fisik berpengaruh positif dan signifikan terhadap kepuasan pelanggan sekaligus yang menjadi faktor pendukung, sedangkan lokasi, promosi tidak berpengaruh positif dan signifikan terhadap kepuasan pelanggan sebagai faktor penghambat.
\end{abstract}

Kata kunci: Bauran Pemasaran Jasa, Kepuasan Pelanggan, Niki Sae Building dan Bogor 


\section{PENDAHULUAN}

Perkembangan industri pemasaran saat ini sangat meningkat denganbanyaknya pesaing. Agar mampu memenangkan dalam persaingan harus membuat dan mencari strategi tepat dalam mengenalkan suatu produk atau usaha yang dijalani.Sehingga para produsen mampu dan berani membuat konsep baru untuk mempertahankan dan memajukan produknya di pasaran, dengan demikian pemasaran merupakan hal prioritas yang berkontribusi dalam perluasan dan pencapaian pemasaran kebutuhan, sehingga diharuskan ketika memulai aktivitas suatu pemasaran dilakukan dengan tepat dan efisien.

Perkembangan bisnis, terutama dalam sektor jasa menciptakan sebuah persaingan begitu juga usaha gedung olahraga, melihat keadaan tersebut, pengusaha gedung olahraga mampu berkompetisi dengan pesaing. Gedung olahraga adalah tempat sarana olahraga yang didalamnya telah tersedia berbagai alat-alat untuk keperluan dan kebutuhan bagi pengguna fasilitas berolahraga. Keberhasilan melakukan pemasaran seperti produk hingga mampu diterima dipasaran tergantung bagaimana memanfaatkan ilmu pemasaran tersebut. Adapun pengertian pemasaran menurut Alma, (2014:1) segala usaha meliputi berbagai pelayanan produk dari sektor produksi ke sektor konsumsi. Sedangkan manajemen pemasaran menurut Alma (2014:130) merupakan suatu bentuk pengelolaan aktivitas pemasaran yang dilakukan baik perorangan ataupun perusahaan.

Kepuasan pelanggan menjadi faktor penting untuk mengembangkan usaha. Saat pelanggan mendapatkan kepuasan, dapat menimbulkan rasa loyalitas tinggi dan senantiasa menggunakan kembali sehingga tidak memberikan pengaruh jasa pihaklain. Seperti halnya Niki Sae Building Bogor bergerak di bidang jasa, yang menyediakan fasilitas sarana olahraga badminton. Berolahraga sekarang bukan lagi menjadi suatu kebutuhan saja, melainkan gaya hidup tersendiri khususnya di wilayah Bogor.

Jasa menurut Alma (2014:243) sesuatu tidak berwujud tetapi mampu untuk memenuhi keinginan pelanggan. Adapun kepuasan pelanggan menurut Lupiyoadi (2014:228) tingkatan yang dirasakan konsumen atas hasil dari kinerja terhadap harapannya, dan faktorfaktor mendukung dalam memuaskan pelanggan dengan bauran pemasaran, dan bauran pemasaran menurut Alma (2014:205) strategi membaurkan aktivitas-aktivitas pemasaran, untuk menggabungkan dan mencari kombinasi terkuat agar mendapatkan hasil yang memuaskan, sedangkan bauran pemasaran jasa menurut Lupiyoadi (2014:92) merupakan satu kesatuan alat pemasaran perlu ada pertimbangan saat merencanakan strategi pemasaran dan penetapan posisi dapat berjalan sukses, dan elemen bauran pemasaran jasa terdiri dari atas tujuh hal (7P) yaitu sebagai berikut, produk, harga, lokasi, promosi, orang, proses, bukti fisik.

Menentukan bauran pemasaran secara efektif akan membantu untuk menigkatkan jumlah pelanggan. Memberikan suatu kepuasan terhadap pelanggan melalui pemberian pelayana terbaik, kemungkinan besar dapat terjadi promosi gratis dalam bentuk dari word of mouth melalui pelanggan tetap ditujukan pada konsumen baru. Berdasarkan data jumlah pelanggan menggunakan jasa sewa lapangan badminton tahun 2016:

\section{Tabel 1. Data Pelanggan Menggunakan Sewa Lapangan Badminton pada Tahun 2016} Niki Sae Building Bogor

\begin{tabular}{|c|c|c|c|}
\hline Bulan & Target (Jam) & Penggunaan (Jam) & Pencapaian (\%) \\
\hline Januari & 265 & 200 & 75.47 \\
\hline Februari & 265 & 180 & 67.92 \\
\hline
\end{tabular}




\begin{tabular}{lccc} 
Maret & 265 & 176 & 66.42 \\
April & 265 & 168 & 63.40 \\
Mei & 265 & 180 & 67.92 \\
Juni & 265 & 40 & 15.09 \\
Juli & 265 & 68 & 25.66 \\
Agustus & 265 & 164 & 61.89 \\
September & 265 & 196 & 73.96 \\
Oktober & 265 & 268 & 101.13 \\
November & 265 & 272 & 102.64 \\
Desember & 265 & 236 & 89.06 \\
\hline \multicolumn{2}{c}{ Rata-rata } & $\mathbf{1 7 9}$ &
\end{tabular}

Berdasarkan data tabel tersebut menunjukkan bahwa Niki Sae Building Bogor mengalami pencapaian target tidak sesuai tujuan perusahaan dalam periode tahun 2016 hanya bulan Oktober dan November yang mencapai target. Hal ini disebabkan berdasarkan hasil observasi dan wawancara dengan 30 orang atau pelanggan kekurangan pada Niki Sae
Building Bogor adalah promosi dan lokasi dimana promosi yang digunakan hanya menggunakan brosur dan personal selling, sedangkan lokasi berada di jalan Raya Sukabumi km 2,5 hampir setiap jam 16:00 wib terkena macet. Ditambah adanya persaingan dengan gedung-gedung olahraga badminton lain dapat dilihat pada tabel:

Tabel 2. Gedung Olahraga Badminton Pesaing Niki Sae Building Bogor

\begin{tabular}{|c|c|c|c|c|}
\hline $\begin{array}{c}\text { Gedung } \\
\text { Olahraga }\end{array}$ & $\begin{array}{c}\text { Harga } \\
\text { Per Jam }\end{array}$ & $\begin{array}{c}\text { Jumlah } \\
\text { Lapangan }\end{array}$ & Kekurangan & Kelebihan \\
\hline Dwi Warna & Rp 25.000 & 1 & $\begin{array}{l}\text { Hanya memiliki satu lapangan badminton sehingga } \\
\text { banyak waktu terbuang untuk menunggu gantian } \\
\text { berolahraga badminton. }\end{array}$ & $\begin{array}{l}\text { Harga sewa lapangan badminton lebih } \\
\text { terjangkau dari kompetitor. }\end{array}$ \\
\hline Srikandi & $\operatorname{Rp} 30.000$ & 4 & $\begin{array}{l}\text { Gedung terlihat kotor, dan ketika hujan atap gedung } \\
\text { bocor sehingga aktivitas olahraga diberhentikan } \\
\text { sampai hujannya reda. }\end{array}$ & $\begin{array}{l}\text { Memiliki jumlah lapangan yang banyak } \\
\text { sehingga pelanggan tidak harus } \\
\text { menunggu lama. }\end{array}$ \\
\hline Sukasari & $\operatorname{Rp} 40.000$ & 3 & $\begin{array}{l}\text { Harga terlalu mahal dibandingkan kompetitor } \\
\text { sehingga tidak ada pelanggan (member) tetapi hanya } \\
\text { konsumen (nonmember). }\end{array}$ & $\begin{array}{l}\text { Tidak ada jadwal tetap sehingga calon } \\
\text { konsumen dapat dengan mudah untuk } \\
\text { memesan lapangan badminton. }\end{array}$ \\
\hline Galaxy & $\operatorname{Rp} 30.000$ & 2 & $\begin{array}{l}\text { Lapangan yang dimiliki hanya dua sehingga ketika } \\
\text { melakukan pemesanan lapangan sulit mendapatkan } \\
\text { jadwal yang kosong. }\end{array}$ & Berada dekat dengan pusat keramaian. \\
\hline
\end{tabular}

Sumber: Data Primer, 2017

Gedung olahraga badminton Dwi Warna jarak $\pm 200 \mathrm{~m}$ dari Niki Sae Building, gedung olahraga badminton Srikandi jarak \pm $4,3 \mathrm{~km}$ dari Niki Sae Building, gedung olahraga badminton Sukasari jarak $\pm 6,1 \mathrm{~km}$ dari Niki Sae Building, gedung olahraga badminton Galaxy jarak \pm 6,7 km dari Niki Sae Building, yang ada sekitar Kecamatan Ciawi Bogor. Oleh karena itu perlu dilakukan penelitian tentang peran bauran pemasaran jasa untuk mencapai kepuasan pelanggan belum optimal.

\section{MATERI DAN METODE}

Pemasaran menurut Kotler dan Keller (2012:5) merupakan suatu bentuk dari aktivitas transaksi melibatkan individu maupun kelompok terhadap pihak lain untuk mencapai keinginan baik produk maupun jasa. Manajemen pemasaran menurut Alma (2014:130) adalah suatu bentuk pengelolaan aktivitas dalam pemasaran dengan tujuan mencapai target yang telah tetapkan. Bauran pemasaran menurut Lupiyoadi (2014: 92) seperangkat atau alat pemasar terdiri dari bagian unsur suatu program pemasaran perlu dipertimbangkan supaya penerapan strategi terhadap pemasaran dan penentuan posisi diinginkan berjalan sesuai rencana, kepuasan pelanggan menurut Lupiyoadi (2014:228) adalah tingkatan yang dirasakan konsumen atas hasil dari kinerja terhadap harapannya. Kerangka pemikiranpenelitian sebagai berikut ini: 


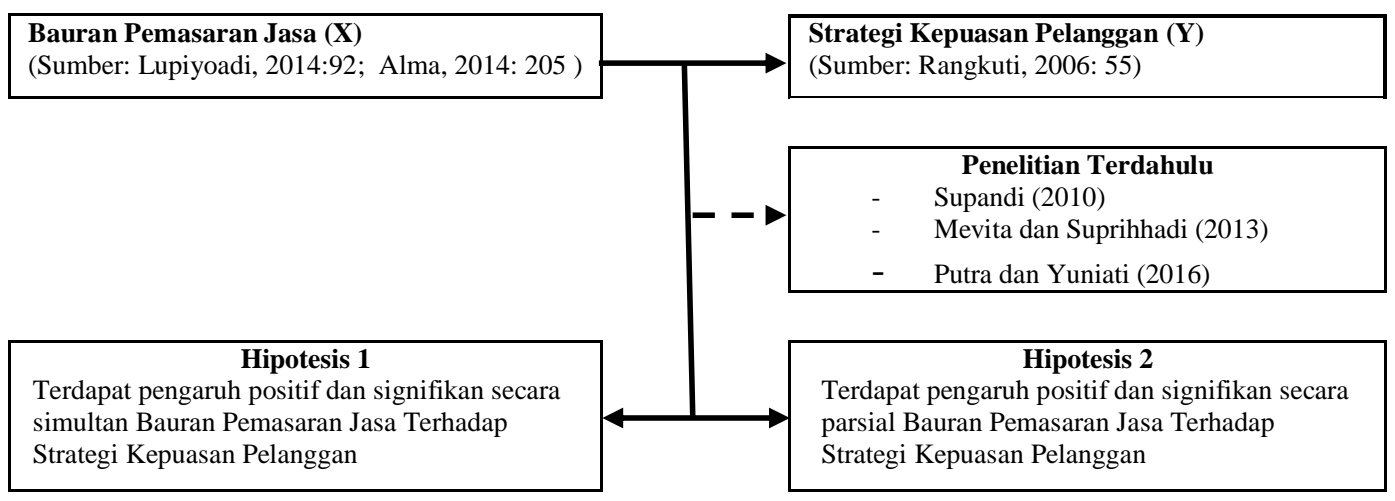

Gambar 1. Kerangka Pemikiran

\section{Metode Penelitian}

Metode penelitian yang digunakan adalah penelitian deskriptif dan verifikatif, dengan pendekatan kuantitatif. Penelitian deskriptif menurut Sugiyono (2016:35) adalah suatu rumusan masalah yang berkenaan dengan pertanyaan terhadap keberadaan variabel mandiri, baik hanya satu variabel atau lebih (variabel berdiri sendiri). Penelitian ini menggunakan data primer dan data sekunder dengan cara studi kepustakaan dan studi lapangan melalui wawancara, observasi dan penyebaran kuesioner.

\section{Operasionalisasi Variabel}

Berikut ini operasionalisasi variabel penelitian berikut ini:

Tabel 3. Operasionalisasi Variabel

\begin{tabular}{|c|c|c|c|c|}
\hline Variabel & Sub Variabel & Konsep Sub Variabel & Indikator & $\begin{array}{l}\text { Skala } \\
\text { Ukur }\end{array}$ \\
\hline \multirow[t]{7}{*}{$\begin{array}{l}\text { Bauran } \\
\text { Pemasaran Jasa } \\
\text { (X) }\end{array}$} & Produk & $\begin{array}{l}\text { Produk sesuatu berwujud dan tidak } \\
\text { berwujud ataupun kombinasi keduanya } \\
\text { yang memberikan nilai dan ditawarkan } \\
\text { kepada konsumen. (Lupiyoadi, 2014:92) }\end{array}$ & $\begin{array}{ll}\text { 1. } & \text { Ruang gedung } \\
\text { 2. } & \text { Luas lapangan } \\
\text { 3. } & \text { Fasilitas sarana } \\
\text { 4. } & \text { Ketersediaan ruang ganti dan toilet }\end{array}$ & Ordinal \\
\hline & Harga & $\begin{array}{l}\text { Nilai jumlah tertentu dipakai untuk } \\
\text { ditukarkan sehingga mendapatkan } \\
\text { produk.(Lupiyoadi, 2014:137) }\end{array}$ & $\begin{array}{ll}\text { 1. } & \text { Tarif } \\
\text { 2. } & \text { Potongan tarif } \\
\text { 3. } & \text { Kesesuaian harga dengan fasilitas }\end{array}$ & Ordinal \\
\hline & Lokasi & $\begin{array}{l}\text { Tempat memberikan pelayanan jasa } \\
\text { ditujukan kepada pelanggan sebagai } \\
\text { alokasi distribusi.(Lupiyoadi, 2014:157) }\end{array}$ & $\begin{array}{ll}\text { 1. } & \text { Strategis } \\
\text { 2. Akses } \\
\text { 3. Lingkungan }\end{array}$ & Ordinal \\
\hline & Promosi & $\begin{array}{l}\text { Alat untuk mempengaruhi konsumen } \\
\text { pada saat pembelian atau penggunaan } \\
\text { sebuah produk. (Lupiyoadi, 2014:178) }\end{array}$ & $\begin{array}{ll}\text { 1. } & \text { Personal selling } \\
\text { 2. } & \text { Brosur }\end{array}$ & Ordinal \\
\hline & Orang & $\begin{array}{l}\text { Orang yang berfungsi sebagai penyedia } \\
\text { jasa sangat mempengaruhi kualitas jasa } \\
\text { yang diberikan.(Lupiyoadi, 2014:97) }\end{array}$ & $\begin{array}{ll}\text { 1. } & \text { Kesopanan } \\
\text { 2. } & \text { Keramahan } \\
\text { 3. } & \text { Penampilan } \\
\end{array}$ & Ordinal \\
\hline & Proses & $\begin{array}{l}\text { Proses merupakan gabungan semua } \\
\text { aktivitas, prosedur, jadwal pekerjaan, } \\
\text { mekanisme, dan semua rutinitas yang } \\
\text { menghasilkan jasa. (Lupiyoadi, } \\
\text { 2014:98) }\end{array}$ & $\begin{array}{l}\text { 1. Kemudahan pemesanan } \\
\text { 2. Kemudahan administrasi }\end{array}$ & Ordinal \\
\hline & Bukti fisik & $\begin{array}{l}\text { Lingkungan fisik perusahaan tempat } \\
\text { jasa diciptakan dan tempat penyedia } \\
\text { jasa.(Lupiyoadi, 2014:94) }\end{array}$ & $\begin{array}{l}\text { 1. Keamanan } \\
\text { 2. Kebersihan } \\
\text { 3. Suasana } \\
\text { 4. Lahan parkir } \\
\end{array}$ & Ordinal \\
\hline $\begin{array}{l}\text { Kepuasan } \\
\text { Pelanggan (Y) }\end{array}$ & $\begin{array}{l}\text { Relationship } \\
\text { Marketing }\end{array}$ & $\begin{array}{l}\text { Merupakan strategi untuk berinteraksi } \\
\text { yang dilakukan penjual dangan pembeli } \\
\text { agar terjalin loyalitas jangka panjang. } \\
\text { (Rangkuti, 2006:55) }\end{array}$ & 1. Hubungan pelanggan dengan marketing & Ordinal \\
\hline
\end{tabular}




\begin{tabular}{|c|c|c|c|}
\hline $\begin{array}{l}\text { Superior Customer } \\
\text { Service }\end{array}$ & $\begin{array}{l}\text { Merupakan strategi dimana perusahaan } \\
\text { berorientasi untuk menawarkan } \\
\text { pelayanan terbaik dibandingkan } \\
\text { kompetitor. } \\
\text { (Rangkuti, 2006:55) }\end{array}$ & 2. Pelayanan & Ordinal \\
\hline $\begin{array}{l}\text { Unconditional } \\
\text { Service Guarantees }\end{array}$ & $\begin{array}{l}\text { Garansi atau jaminan mutlak dirancang } \\
\text { untuk meringankan risiko pelanggan, } \\
\text { suatu ketidakpuasan yang dirasakan } \\
\text { setelah membayar produk ataupun jasa } \\
\text { (Rangkuti, 2006:55) }\end{array}$ & 3. Garansi atau jaminan & Ordinal \\
\hline $\begin{array}{l}\text { Penanganan Keluhan } \\
\text { yang Efisien }\end{array}$ & $\begin{array}{l}\text { Penanganan keluhan yang dirasakan } \\
\text { seseorang karena tidak mendapatkan } \\
\text { kepuasan dan merubahnya sehingga } \\
\text { mendapatkan kepuasan.(Rangkuti, } \\
\text { 2006:55) }\end{array}$ & 4. Penanganan keluhan pelanggan & Ordinal \\
\hline $\begin{array}{l}\text { Peningkatan Kinerja } \\
\text { Perusahaan }\end{array}$ & $\begin{array}{l}\text { Melakukan pengamatan dan mengukur } \\
\text { tingkat kepuasan pelanggan secara } \\
\text { berkala, dan memberikan pendidikan } \\
\text { serta pelatihan terkait komunikasi, } \\
\text { salesmanship.(Rangkuti, 2006:55) }\end{array}$ & $\begin{array}{ll}\text { 5. } & \text { Komunikasi } \\
\text { 6. } & \text { Salesmanship (tenaga penjual) }\end{array}$ & Ordinal \\
\hline
\end{tabular}

\section{Pengambilan Sampel}

Metode pengambilan jumlah sampel dengan teknik non-probability sampling melalui incidental sampling. Teknik pengumpulan sampel menggunakan rumus Roa Purba, Handal (2010:34) sebagai berikut:

dibulatkan 100

$$
\mathrm{N}=\frac{\mathrm{Z}^{2}}{4(\mathrm{moe})^{2}} ; \quad \mathrm{N}=\frac{(1,96)^{2}}{4(0,1)^{2}}=96,04
$$

dimana: $\mathrm{N}=$ jumlah sampel; $\mathrm{Z}=$ tingkat distribusi normal pada taraf signifikasi 5\% $(1,96)$

moe $=$ margin of error max, adalah tingkat kesalahan maksimal penarikan sebuah sampel dengan ditoleransi sebesar $10 \%$.

Berdasarkan penghitungan tersebut maka diperoleh 100 responden.

\section{Metode Pengujian Data Instrumen}

Untuk melakukan uji validitas, uji reliabilitas menggunakan perangkat komputer program (SPSS) versi 22.0. Tolak ukur uji validitas berdasarkan pada nilai $\mathrm{r}_{\text {hitung }}$ (Corrected Item Total Correlation) $\geq$ $\mathrm{r}_{\text {tabel }}$ sebesar $0,3, \alpha=0,05$, maka semua item pernyataan dianggap valid dan dilanjutkan pengujian berikut. Sedangkan pengujian reliabilitas nilai diatas 0,6 sehingga semua item tersebut dinyatakan reliabel.

Dilakukan pengujian asumsi klasik agar mendapatkan hasil terbaik oleh Gujarati (2006:97) asumsi klasik digunakan supaya model regresi cukup tidak bias, seperti: 1) uji normalitas bahwa nilai residual berdistribusi dengan normal; 2) uji multikolineritas bahwa model regresi tidak menimbulkan gejala multikolineritas; 3) uji heterokedastisitas bahwa tidak menimbulkan gejala heterokedastisitas.

\section{Metode Analisis Data}

Data yang didapatkan akan dianalisis secara verifikatif dengan mengunakan uji statistik. Melalui kuesioner model tertutup dengan Skala Likert, yaitu dari satu sampai lima pada butir kuesioner. Analisis regresi ganda mepredikasi suatu keadaan (naik turunnya) variabel dependen (kriterium), bila dua atau lebih variabel independen sebagai faktor predictor Sugiyono (2016:188). Apabila dituangkan dalam suatu model, akan didapatkan hubungan variabel penelitian sebagai berikut: 


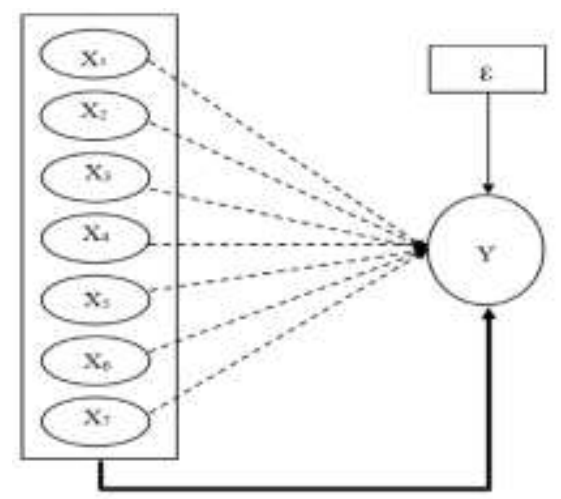

\section{Gambar 2. Hubungan Antara Variabel Penelitian}

dimana: $\longrightarrow=$ Pengaruh simultan; $--\rightarrow=$ pengaruh parsial; $\longrightarrow=$ pengaruh error Penggunaan regresi berganda dipakai dalam $\quad Y=a+b_{1} X_{1}+b_{2} X_{2}+b_{3} X_{3}+b_{4} X_{4}+b_{5} X_{5}+$ pengujian besaran pengaruh variabel$\mathrm{b}_{6} \mathrm{X}_{6}+\mathrm{b}_{7} \mathrm{X}_{7}$

variabel independen/bebas terhadap variabel Uji statistik menggunakan uji secara dependen/terkait. simultan (uji F) dan uji secara parsial (uji t).

\section{HASIL PENELITIAN}

Adapun hasil penelitian berikut ini:

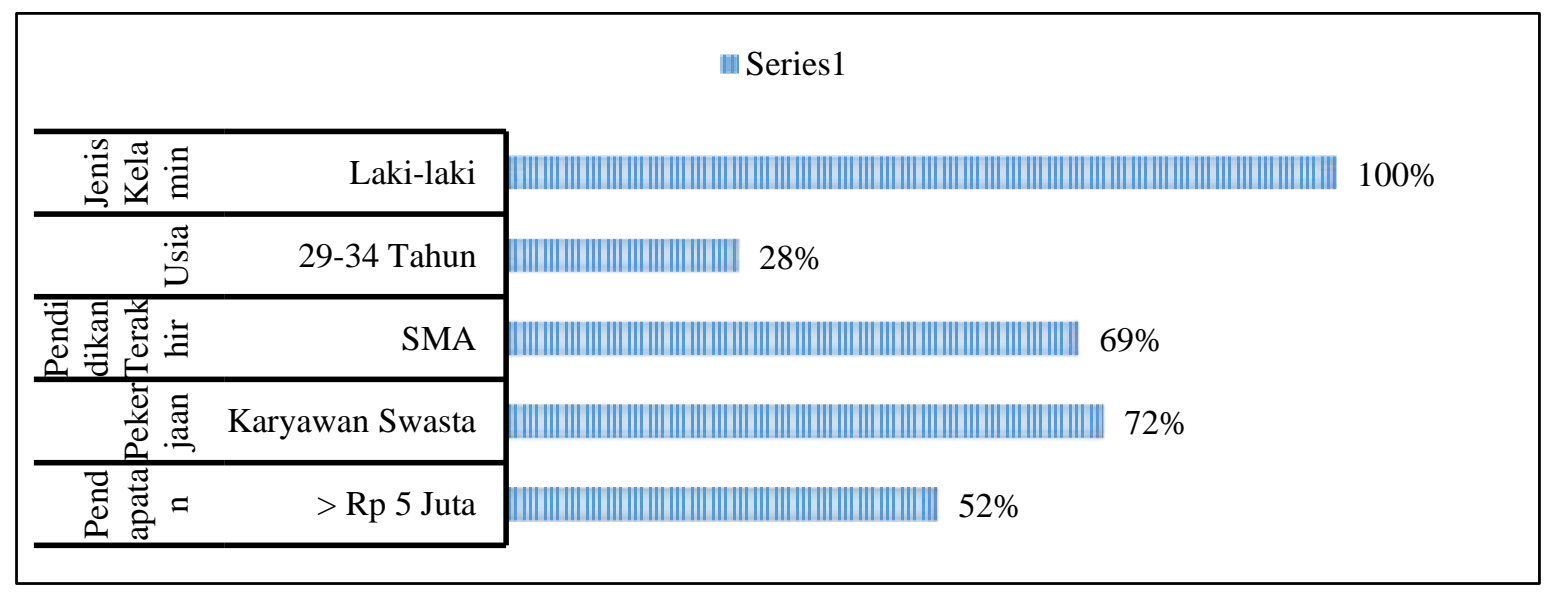

Gambar 3. Rekapitulasi Karakteristik Pelanggan

Sumber: Data primer diolah, 2017

Berdasarkan gambar tersebut menunjukkan mayoritas karakteristik pelanggan jenis kelamin laki-laki dengan berusia 29-34 tahun yang memiliki latar belakang pendidikan akhir SMA memiliki pekerjaan swasta (karyawan swasta) serta pendapatan diatas Rp 5.000.000 per bulan. Sedangkan rekapitulasi tanggapan pelanggan terhadap bauran pemasaran jasa berikut ini. 


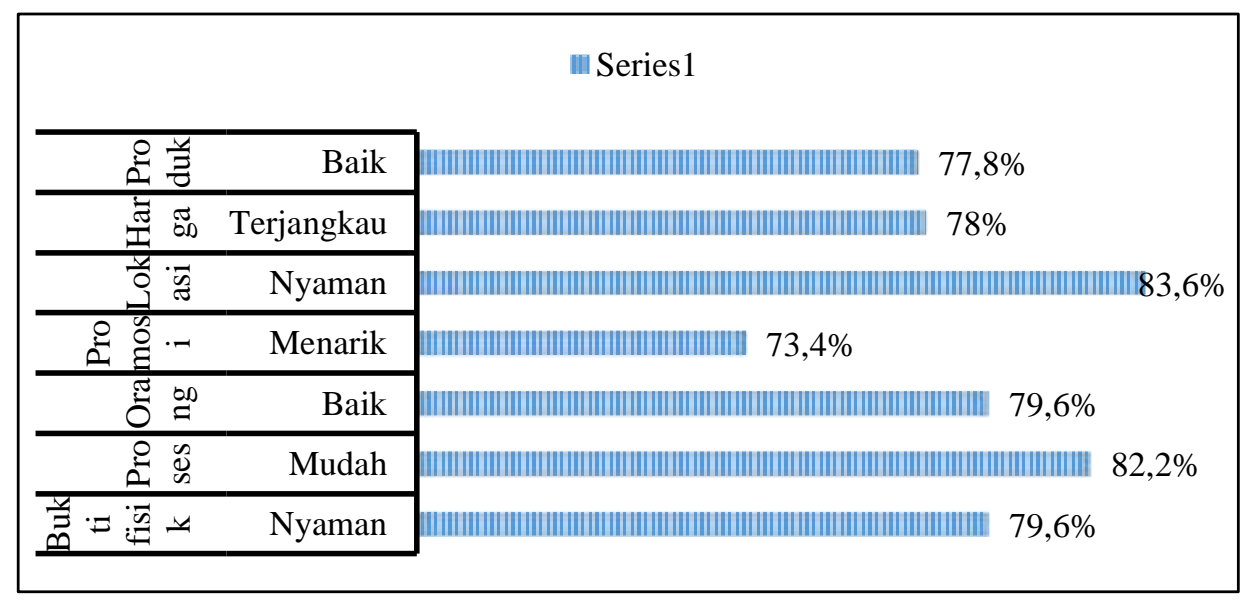

\section{Gambar 4. Rekapitulasi Tanggapan Pelanggan Terhadap Bauran Pemasaran Jasa}

Sumber: Data primer diolah, 2017

Berdasarkan gambar tersebut, promosi, sehingga harus ada peningkatan diketahui tanggapan pelanggan terhadap promosi yang diberikan kepada pelanggan variabel bauran pemasaran dengan nilai seperti dengan memperluas penyebaran brosur terbesar adalah 82,2 persen pada variabel dan menambah alat promosi seperti melalui proses yang dapat diartikan proses jasa pada media sosial. Rekapitulasi tanggapan Niki Sae Building Bogor telah mencapai pelanggan terhadap kepuasan pelanggan harapan pelanggan, sedangkan nilai tertinggi berikut ini. terkecil sebesar 73,4 persen pada variabel

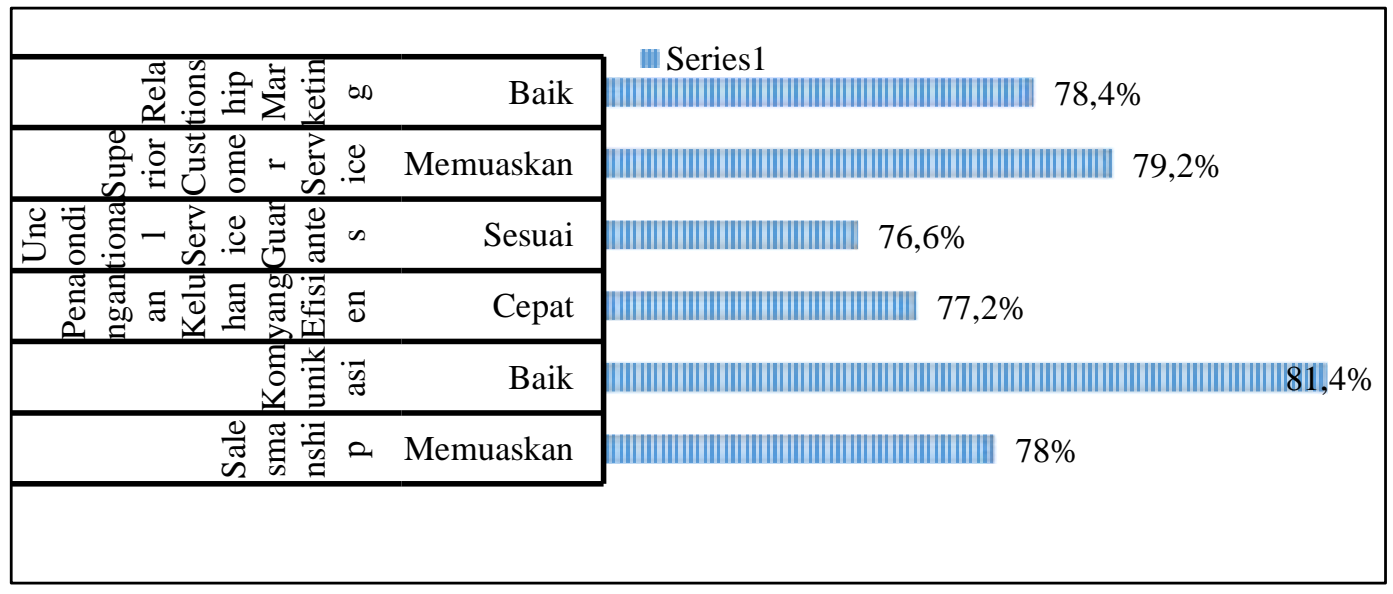

Gambar 5. Rekapitulasi Tanggapan Pelanggan Terhadap Kepuasan Pelanggan

Sumber: Data kuesioner diolah, 2017

Hasil dari rekapitulasi menunjukkan tanggapan pelanggan terhadap variabel kepuasan pelanggan dengan nilai rata-rata sebesar 78,4 persen, melalui kriteria penilaian tertinggi 81,4 persen adalah komunikasi, dapat diartikan pihak perusahaan telah memberikan pelayanan melalui komunikasi terhadap pelanggan dengan baik, sedangkan nilai terkecil 76,6 persen adalah garansi atau jaminan, sehingga diperlukan adanya penyederhanaan prosedur atau mekanisme dalam proses untuk melakukan kemudahan menggunakan garansi. Berdasarkan penghitungan dengan menggunakan program Software Statistical Program for Social Science (SPSS) versi 22.0 diperoleh hasil sebagai berikut: 
Tabel 4. Rangkuman Hasil Penghitungan Bauran Pemasaran Jasa Terhadap Kepuasan Pelanggan

\begin{tabular}{|c|c|c|c|c|c|c|}
\hline \multicolumn{7}{|c|}{ Coefficients $^{\mathrm{a}}$} \\
\hline & \multirow[t]{2}{*}{ Model } & \multirow{2}{*}{\multicolumn{2}{|c|}{ Unstandardized Coefficients }} & \multirow{2}{*}{$\begin{array}{r}\text { Standardized } \\
\text { Coefficients }\end{array}$} & \multirow{2}{*}{$\mathbf{t}$} & \multirow{2}{*}{ Sig. } \\
\hline & & & & & & \\
\hline \multirow{17}{*}{1} & (Constant) & 107 & 1234 & & 086 & \\
\hline & Produk & 221 & 093 & 144 & 2,382 & 019 \\
\hline & Harga &, 481 &, 122 & 276 & 3,945 &, 000 \\
\hline & Lokasi & 025 & 103 & 014 &, 242 & 810 \\
\hline & Promosi & ,032 & 158 & 012 & ,201 & 841 \\
\hline & Orang & 290 & 133 & 154 & 2,181 &, 032 \\
\hline & Proses & ,783 & 150 &, 322 & 5,218 &, 000 \\
\hline & Bukti Fisik & ,272 & 103 &, 172 & 2,646 & 010 \\
\hline & $\mathrm{t}$-tabel & 1,98 & & & & \\
\hline & F-hitung & 68,595 & & & & \\
\hline & Sig & 0,000 & & & & \\
\hline & F-tabel & 2,20 & & & & \\
\hline & $\mathrm{R}$ & 0,916 & & & & \\
\hline & R Square & 0,839 & & & & \\
\hline & Adjusted R & 0,827 & & & & \\
\hline & SEE & 1,27268 & & & & \\
\hline & Alpha & $5 \%$ & & & & \\
\hline
\end{tabular}

Berdasarkan ringkasan hasil perhitungan menggunakan regresi berganda bahwa yang digunakan dapat menjelaskan 83,9 persen dari variabel dependent. Secara keseluruhan ini signifikan pada tingkat kepercayaan 95 persen. (F-hitung 68,595). Sedangkan sisanya 16,1\% dipengaruhi faktor-faktor lain yang tidak

\section{PEMBAHASAN}

\section{Pengaruh bauran pemasaran jasa terhadap kepuasan pelanggan}

Berdasarkan hasil perhitungan bahwa $F_{\text {hitung }}$ sebesar 68,595 lebih besar dari $F_{\text {tabel }}$ 2,20 , dengan probabilitas 0,000 , dan menggunakan batas signifikasi 0,05 maka Ho ditolak dan $\mathrm{Ha}$ diterima. Hal ini menurut Hurriyati (2010:48) bahwa bauran pemasaran merupakan unsur-unsur pemasaran yang saling terkait, dibaurkan, diorganisir dan digunakan dengan tepat, sehingga perusahaan dapat mencapai tujuan pemasaran efektif, sekaligus memuaskan kebutuhan dan keinginan konsumen. Mohsan (2011:263) bahwa kepuasan pelanggan adalah keseluruhan dari sikap dan atau perilaku pelanggan terhadap pemberian pelayanan, atau sebuah reaksi emosional terjadi karena perbedaan antara diteliti seperti: citra perusahaan. Sehingga model ini cukup memadai untuk digunakan sebagai alat analisis. Secara parsial produk, harga, orang, proses dan bukti fisik berpengaruh terhadap kepuasan pelanggan. Sedangkan lokasi dan promosi tidak berpengaruh terhadap kepuasan pelanggan.

harapan dan kenyataan, mengenai pemenuhan beberapa kebutuhan, keinginan atau tujuan. Sama halnya dengan penelitian Wulan dkk (2016) secara bersama-sama (simultan) bauran pemasaran jasa berpengaruh positif dan signifikan terhadap kepuasan pelanggan. Begitupun dengan hasil penelitian Gultom (2017) menyatakan bahwa variabel bauran pemasaran jasa secara bersama-sama (simultan) berpengaruh positif dan signifikan terhadap kepuasan konsumen.

\section{Pengaruh produk terhadap kepuasan pelanggan}

Hasil pengujian diperoleh nilai thitung untuk variabel produkterhadap kepuasan pelanggan menunjukkan nilai sebesar 2,382 dengan probabilitas 0,019. Adapun derajat kebebasan $t_{\text {tabel }}$ sebesar 1,98 dan menggunakan batas signifikasi $0,05, t_{\text {hitung }}>t_{\text {tabel }}$ dan sig $<\alpha$ maka 
Ho ditolak dan Ha diterima. Produk mampu membuat para pelanggannya puas serta memberikan dampak terhadap rasa loyal disebabkan karena adanya pengembanganpengembangan dilakukan oleh para pemasar seperti, menyediakan variasi produk beragam sesuai kebutuhan pelanggan, merancang produk agar memiliki citra atau nama cukup dapat dibanggakan oleh para pelanggan dalam menggunakannya, serta penyediaan atau penyampaian fungsi dan manfaat produk dengan diiringi kualitas pelayanan memuaskan ditujukan kepada para pelanggan juga sangat dapat mempengaruhi tingkat kepuasan para pelanggan. Penelitian Supandi (2010) produk memiliki pengaruh positif dan signifikan terhadap kepuasan konsumen. Begitupun dengan hasil penelitian dilakukan Mevita dan Suprihhadi (2013) adanya pengaruh positif dan signifikan produk terhadap kepuasan konsumen. Terdapat pengaruh positif dan signifikan antara produk terhadap kepuasan pelanggan dikemukakan pula pada penelitian Putra (2016).

\section{Pengaruh harga terhadap kepuasan pelanggan}

Hasil pengujian diperoleh nilai $t_{\text {hitung }}$ untuk variabel harga terhadap kepuasan pelanggan menunjukkan nilai sebesar 3,945 dengan probabilitas 0,000. Adapun derajat kebebasan $t_{\text {tabel }}$ sebesar 1,98 dan menggunakan batas signifikasi 0,05 , $t_{\text {hitung }}>\mathrm{t}_{\text {tabel }}$ dan sig $<\alpha$ maka Ho ditolak dan Ha diterima. Menurut Assauri (2013:118) harga merupakan beban atau nilai bagi konsumen, yang didapatkan dengan memperoleh dan menggunakan suatu produk atau jasa. Penelitian ini sejalan dengan penelitian Deden (2012) bahwa secara parsial harga berpengaruh positif dan signifikan terhadap kepuasan siswa. Sama halnya hasil penelitian Citra (2014) secara parsial harga berpengaruh positif dan signifikan terhadap kepuasan konsumen. Begitupun hasil penelitian Suriyani (2017) bahwa secara parsial harga berpengaruh positif dan signifikan terhadap kepuasan konsumen.

\section{Pengaruh lokasi terhadap kepuasan pelanggan}

Hasil pengujian diperoleh nilai thitung untuk variabel lokasi terhadap kepuasan pelanggan menunjukkan nilai sebesar 0,242 dengan probabilitas 0,810 . Adapun derajat kebebasan $t_{\text {tabel }}$ sebesar 1,98 dan menggunakan batas signifikasi $0,05, t_{\text {hitung }} \leq \mathrm{t}_{\text {tabel }}$ dan sig $>\alpha$ maka Ho diterima dan Ha ditolak. Hal ini dapat diartikan jika pelanggan sudah mendapatkan kepuasan dan tidak melihat kriteria lokasi strategis, maka lokasi tidak berpengaruh terhadap kepuasan pelanggan. Penelitian ini sejalan dengan penelitian Diajeng (2011) bahwa secara parsial lokasi tidak berpengaruh positif dan signifikan terhadap kepuasan pengguna. Sama halnya hasil penelitian Tasman (2013) mengatakan jika secara parsial lokasi tidak berpengaruh positif dan signifikan terhadap kepuasan layanan jasa. Begitupun hasil penelitian Tasya, dkk (2014) mengatakan juga secara parsial lokasi tidak berpengaruh positif dan signifikan terhadap kepuasan konsumen.

\section{Pengaruh promosi terhadap kepuasan pelanggan}

Hasil pengujian diperoleh nilai thitung untuk variabel promosi terhadap kepuasan pelanggan menunjukkan nilai sebesar 0,201 dengan probabilitas 0,841 . Adapun derajat kebebasan $t_{\text {tabel }}$ sebesar 1,98 dan menggunakan batas signifikasi $0,05, t_{\text {hitung }} \leq \mathrm{t}_{\text {tabel }}$ dan sig $>\alpha$ maka Ho diterima dan $\mathrm{Ha}$ ditolak. Hal ini dapat diartikan jika pelanggan sudah menyukai dan berada pada zona nyaman, maka promosi tidak berpengaruh terhadap kepuasan pelanggan. Sejalan dengan penelitian Sispandri, dkk (2011) bahwa secara parsial promosi tidak berpengaruh positif dan signifikan terhadap kepuasan konsumen. Sama halnya hasil penelitian Muhamad (2015) mengatakan jika secara parsial promosi tidak berpengaruh positif dan siginifikan terhadap kepuasan konsumen. Begitupun hasil penelitian Farida, dkk (2016) mengatakan juga secara parsial promosi tidak berpengaruh 
positif dan signifikan terhadap kepuasan pelanggan

\section{Pengaruh orang terhadap kepuasan pelanggan}

Hasil pengujian diperoleh nilai $\mathrm{t}_{\text {hitung }}$ untuk variabel orang terhadap kepuasan pelanggan menunjukkan nilaisebesar 2,181 dengan probabilitas 0,032. Adapun derajat kebebasan $t_{\text {tabel }}$ sebesar 1,98 dan menggunakan batas signifikasi $0,05, t_{\text {hitung }}>t_{\text {tabel }}$ dan $\operatorname{sig}<\alpha$ maka Ho ditolak dan Ha diterima. Menurut Hutasoit (2011:25) sesuai dengan konsep kepuasan konsumen, bahwa kepuasan konsumen dapat tercipta bila kinerja atau hasil dirasakan sesuai harapan konsumen. Jadi baik atau buruknya pelayanan diberikan oleh perusahaan, sangatlah mempengaruhi kepuasan konsumen. Sejalan dengan penelitian Fitriyani (2012) mengatakan bahwa secara parsial orang berpengaruh positif dan signifikan terhadap loyalitas nasabah. Sama halnya hasil penelitian dilakukan oleh Ade dan Eka (2013) secara parsial orang berpengaruh positif dan signifikan terhadap kepuasan nasabah.

\section{Pengaruh proses terhadap kepuasan pelanggan}

Hasil pengujian diperoleh nilai thitung untuk variabel proses terhadap kepuasan pelanggan menunjukkan nilaisebesar 5,214 dengan probabilitas 0,000 . Adapun derajat kebebasan tabel sebesar 1,98 dan menggunakan batas signifikasi 0,05 , $t_{\text {hitung }}>t_{\text {tabel }}$ dan sig $<\alpha$ maka Ho ditolak dan Ha diterima. Menurut Hurriyati (2010:64) semua upaya perusahaan dalam menjalankan dan melaksanakan aktivitasnya untuk memenuhi kebutuhan dan keinginan konsumennya. Hasil penelitian ini sejalan dengan penelitian dilakukan Devi (2011) bahwa secara parsial proses berpengaruh positif dan signifikan terhadap kepuasan konsumen. Begitupun hasil penelitian Suri dan Ayu (2016) secara parsial proses berpengaruh positif dan signifikan terhadap kepuasan konsumen.

\section{Pengaruh bukti fisik terhadap kepuasan pelanggan}

Hasil pengujian diperoleh nilai thitung untuk variabel bukti fisik terhadap kepuasan pelanggan menunjukkan nilai sebesar 2,646 dengan probabilitas 0,010 . Adapun derajat kebebasan $t_{\text {tabel }}$ sebesar 1,98 dan menggunakan batas signifikasi $0,05, t_{\text {hitung }}>t_{\text {tabel }}$ dan sig $<\alpha$ maka Ho ditolak dan $\mathrm{Ha}$ diterima. Hal ini Effendi (2010:349) menjelaskan bahwa bukti fisik merupakan satu hal yang secara nyata turut mempengaruhi keputusan konsumen untuk membeli dan menggunakan produk atau jasa ditawarkan, dengan kata lain bukti fisik yang menarik dan unik akan menjadi daya tarik konsumen membeli suatu produk atau jasa. Hasil penelitian ini sejalan dengan penelitian Elisabeth (2011) bahwa secara parsial bukti fisik berpengaruh positif dan signifikan terhadap kepuasan mahasiswa.

\section{Faktor pendukung dan penghambat}

Hasil penghitungan uji t memiliki lima sub variabel dengan nilai $t_{\text {hitung }}>t_{\text {tabel }}$ maka dapat dikatakan produk, harga, orang, proses, dan bukti fisik berpengaruh terhadap kepuasan pelanggan sekaligus menjadi faktor pendukung. Sedangkan dua variabel lokasi, promosi memiliki nilai $t_{\text {hitung }} \leq t_{\text {tabel }}$ sehingga tidak berpengaruh terhadap kepuasan pelanggan dan menjadi faktor penghambat.Dari sisi lokasi, Niki Sae Building Bogor memiliki lokasi cukup strategis berada di samping jalan Raya Sukabumi-Bogor merupakan kemacetan selalu terjadi sehingga menurunkan minat para pelanggan untuk berkunjung ke Niki Sae Building Bogor. Jauh dekatnya lokasi usaha tidak mempengaruhi minat pelanggan untuk datang dikarenakan pelanggan sudah mendapatkan kepuasan yang sesuai yang diinginkan. Dengan sarana promosi terbatas seperti personal selling dan brosur, tidak menggunakan bauran promosi dengan maksimal yang pada akhirnya pengenalan produk menjadi terhambat. 


\section{SIMPULAN DAN IMPLIKASI}

Berdasarkan uraian tersebut dapat disimpulkan bahwa: 1) hasil rekapitulasi tanggapan pelanggan terhadap pelaksanaa elemen bauran pemasaran jasa menyatakan bahwa nilai terbesar adalah proses adapun nilai terkecil ialah produk. Sedangkan hasil rekapitulasi tanggapan pelanggan terhadap pelaksanaa strategi kepuasan pelanggan menyatakan jika nilai terbesar adalah komunikasi dan nilai terkecil ialah garansi atau jaminan; 2) uji secara simultan (bersamasama) bahwa bauran pemasaran jasa memiliki pengaruh positif dan signifikan terhadap kepuasan pelanggan pada Niki Sae Building Bogor; 3) uji secara parsial menunjukkan bahwa produk, harga, orang, proses, dan bukti fisik, berpengaruh positif dan signifikan terhadap kepuasan pelanggan pada Niki Sae Building Bogor sekaligus menjadi faktor pendukung. Sedangkan sisanya lokasi, promosi tidak berpengaruh positif dan signifikan terhadap kepuasan pelanggan pada Niki Sae Building Bogor dan menjadi faktor penghambat.

Berdasarkan dari hasil penelitian dan pembahasan maka implikasi berikut ini: a) peningkatan place (lokasi) dengan cara antar jemput pelanggan dan melibatkan tukang ojek setempat; b) mengoptimalkan promotion (promosi) melalui perluasan penyebaran brosur dan menambah alat promosi seperti media sosial; c) garansi atau jaminan (unconditional service guarantees) diperlukan adanya penyederhanaan prosedur atau mekanisme dalam proses untuk melakukan kemudahan menggunakan garansi; d) bagi penelitian berikutnya dapat menambah variabel seperti citra perusahaan dengan memperbanyak jumlah sampel dan variasi alternatif lokasi penelitian.

\section{UCAPAN TERIMA KASIH}

Ucapan terima kasih kepada pengelola

Niki Sae Building Bogor yang telah memberikan ijin kepada penulis untuk melakukan penelitian diperusahaannya.

\section{DAFTAR PUSTAKA}

Assauri, Sofjan. 2013. Manajemen Pemasaran. Jakarta. Rajawali Pers.

Buchari, Alma. 2014. Manajemen Pemasaran dan Pemasaran Jasa. Bandung. Alfabeta.

Citrta, Suci, Mantauv. 2014. Pengaruh Harga Dan Keberagaman Produk Terhadap Kepuasan Konsumen. e-Jurnal Apresiasi Ekonomi Vol. 3, No. 1, hal. 7.

Dedek, Kurniawan, Gultom. 2017. Pengaruh Bauran Pemasaran Jasa Terhadap Citra Destinasi Dan Kepuasan Wisatawan Serta Implikasinya Terhadap Loyalitas Wisatawan. Jurnal Riset Sains Manajemen Vol. 1, No. 2, hal 147.

Deden, Edwar, Yokeu, Bernardin. 2013. Pengaruh Bauran Pemasaran Jasa Pendidikan Terhadap Tingkat Kepuasan Siswa Pada SMA PGRI Kurnia Garut. Jurnal Ekonomi, Manajemen, dan Bisnis Vol. 1, No. 2, hal. 10.

Devi, Anita, Subagyo. 2011. Pengaruh Bauran Pemasaran dalam Restoran Terhadap Kepuasan dan Loyalitas Konsumen Pada Rumah Makan Lestari. Skripsi Sarjana. Fakultas Ekonomi Universitas Jember.

Diajeng, Variant. 2011. Pengaruh Bauran Pemasaran Terhadap Kepuassan Pengguna Universitas Ciputra Library Surabaya. Jurnal Manajemen Airlangga Vol. 4, No. 2, hal. 8.

Effendi, Ridwan. 2010. Pendidikan Lingkungan Sosial, Budaya, dan Teknologi. Bandung.CV. Maulana Media Grafik.

Elisabeth Koes Soedijati. 2011. Pengaruh Bauran Pemasaran Perguruan Tinggi Terhadap Kepuasan dan Dampaknya Kepada Loyalitas Mahasiswa Pada Tiga PTS. Jurnal Bina Ekonomi Vol. 15, No. 2, hal. 101.

Faizan, Mohsan. 2011. Impact of Customer Satisfaction on Customer Loyalty and Intentions to Switch: Evidence from Banking Sector of Pakistan.

Farida, dkk, 2016. Analisis Pengaruh Bauran

Pemasaran 7P Terhadap Kepuasan 
Pelanggan Pengguna Gojek Online. Jurnal Riset Manajemen dan Bisnis Vol. 1, No. 1, hal. 38.

Fitriyani Dayasti Hasan. 2012. Pengaruh Bauran Pemasaran Jasa Terhadap Loyalitas Nasabah Pada PT. Bank Rakyat Indonesia (Persero) Tbk. Skripsi Sarjana. Jurusan Manajemen Universitas

Hasanuddin. Makasar.

Gujarati, Damodar. 2006. Dasar-Dasar Ekonometrika. Jakarta. Erlangga.

Hasibuan, Melayu. 2013. Manajemen Sumber

Daya Manusia. Jakarta. PT Bumi Aksara.

Hurriyati, Ratih. 2010. Bauran Pemasaran dan Loyalitas Konsumen. Bandung. ALFABETHA.

Hutasoit. 2011. Pelayanan Public Teori Dan Aplikasi. Jakarta. MAGNA Script.

Kotler, Philip dan Kevin Lane Keller. 2012.

Manajemen Pemasaran. Jilid I. Edisi Ke Dua Belas. Jakarta. Erlangga.

Lupiyoadi, Rambat. 2014. Manajemen Pemasaran Jasa. Edisi 3. Jakarta. Salemba Empat.

Mevita dan Suprihhadi. 2013. Pengaruh Bauran Pemasaran Jasa Terhadap Kepuasan Konsumen Pembelian Produk PT. Preshion Engineering Plastec. Jurnal Ilmu dan Riset Manajemen Vol. 2, No. 9, hal. 16.

Muhamad, Mufti, Aziz. 2015. Pengaruh Bauran Pemasaran (7P) Terhadap Loyalitas Melalui Kepuasan Konsumen Pondok Bangladesh Rajanya Mie Aceh. Skripsi Sarjana. Fakultas Ekonomi Institut Pertanian Bogor.

Putra dan Yuniati. 2016, Pengaruh Bauran Pemasaran Jasa Terhadap Kepuasan Pelanggan Pada PT. Telekomunikasi Tbk. Jurnal Ilmu dan Riset Manajemen Vol. 5, No. 2, hal. 12..

Rangkuti, Freddy. 2006. Measuring Customer Satisfaction. Jakarta. Gramedia Pustaka Utama.

Rao, Purba. 2006. Measuring Consumer Perception Through Factor Analysis. The Asian Manager (February-March).
Riduan dan Sunarto. 2007. Pengantar Statistik. Bandung. CV. Alfabeta.

Sugiyono. 2016. Metode Penelitian Kuantitatif, Kualitatif, dan R\&D. Bandung. Alfabeta.

Sudjinah, dkk. 2015. Pengaruh Bauran Pemasaran Jasa Terhadap Kepuasan Nasabah Pada KUR BRI Cabang Balikpapan. Seminar Nasional Ekonomi Manajemen dan Akuntansi (SNEMA) Fakultas Ekonomi. Universitas Negeri Padang. SNEMA-2015. ISBN: 978-60217129-5-5.

Supandi. 2010. Pengaruh Bauran Pemasaran Jasa Terhadap Kepuasan Konsumen PT. Nusa Tongkainan Wisata Tirta Manado. Jurnal Pendidikan Manajemen Bisnis Vol. 9, No. 17, hal. 23.

Suri, Amila, dan Ayu, Novianti. 2016. Pengaruh Bauran Pemasaran Terhadap Kepuasan Konsumen Pada Warung Kanasha. Jurnal Manajemen dan Keuangan Vol. 5, No. 1, hal. 467.

Suriyani. 2017. Pengaruh Bauran Pemasaran Terhadap Kepuasan Konsumen Pengguna Layanan 4G Telkomsel, e-Jurnal Administrasi Bisnis Vol. 5, No. 2, hal. 507-508.

Tasman H, Taher. 2013. Pengaruh Bauran Pemasaran Terhadap Kepuasan Layanan Jasa Pendidikan. Jurnal Sains Manajemen Vol. 11, No. 2, hal. 8.

Tisye, dkk. 2014. Bauran Pemasaran Jasa Terhadap Kepuasan Konsumen di Hello Tours and Travel, Jurnal EMBA, Vol. 2, No. 3, hal. 408.

Wicaksono, Teguh. 2017. Pengaruh Dimensi Kualitas Pelayanan Terhadap Kepuasan Pelanggan Pada Upik Futsal Banjarmasin. Jurnal Ilmiah Manajemen Vol. 1, No. 2, hal. 50-51.

Wulan, dkk. 2016. Pengaruh Bauran Pemasaran Jasa Terhadap Keputusan Pembelian Serta Dampak Terhadap Kepuasan Pelanggan (Studi Pada Restoran Kayu Manis Tuban). Jurnal Administrasi Bisnis (JAB) Vol. 38, No. 2, hal. 177-178. 